\title{
УДК 378.147:811.111 \\ ІНФОКОМУНІКАЦІЙНА ТЕХНОЛОГІЯ ПОДКАСТИНГУ В СИСТЕМІ ВПРАВ ДЛЯ НАВЧАННЯ МАЙБУТНІХ ІНЖЕНЕРІВ-МЕХАНІКІВ АНГЛІЙСЬКОГО МОНОЛОГІЧНОГО МОВЛЕННЯ
}

\author{
Ващило О. В. \\ olga_vv@ukr.net \\ Національний технічний університет Украӥни \\ “Київський політехнічний інститут імені Ігоря Сікорського” \\ Дата надходження 30.10.2018. Рекомендовано до друку 29.11.2018.
}

\begin{abstract}
Анотація. Статтю присвячено питанню використання інфокомунікаційної технології подкастингу при розробленні системи вправ для навчання майбутніх інженерів-механіків англійського професійно орієнтованого монологічного мовлення. Проаналізовано методичні властивості сервісу подкастів для обгрунтування доцільності його використання для окресленого навчання. Визначено поняття “система вправ”, перераховано загальнодидактичні й методичні принципи їі створення. Виділено й систематизовано навички й уміння монологічного мовлення, визначено етапи навчання й окреслено завдання кожного з них. Названі особливості організації позааудиторної роботи студентів 3 використанням сервісу подкастів. Охарактеризовано розроблену систему вправ для навчання майбутніх інженерів-механіків англійського професійно орієнтованого монологічного мовлення з використанням інфокомунікаційної технології подкастингу.

Ключові слова: англійське професійно орієнтоване монологічне мовлення, інфокомунікаційна технологія подкастингу, сервіс подкастів, подкаст, система вправ.
\end{abstract}

Ващило О. В. Национальный технический университет Украины “Киевский политехнический институт имени Игоря Сикорского"

Инфокоммуникационная технология подкастинга в системе упражнений для обучения будущих инженеров-механиков английской монологической речи

Аннотация. В статье рассматривается вопрос использования инфокоммуникационной технологии подкастинга при разработке системы упражнений для обучения будущих инженеров-механиков английской профессионально ориентированной монологической речи. Проанализированы методические свойства сервиса подкастов для обоснования возможности его использования в указанных целях. Определено понятие “система упражнений”, перечислены общедидактические и методические принципы ее разработки. Выделены и систематизированы навыки и умения монологической речи, выделены этапы организации процесса обучения, определены задания каждого этапа. Названы особенности организации внеаудиторной работы студентов с использованием сервиса подкастов. Представлена характеристика разработанной системы упражнений для обучения будущих инженеров-механиков английской профессионально ориентированной монологической речи с использованием инфокоммуникационной технологии подкастинга.

Ключевые слова: английская профессионально ориентированная монологическая речь, инфокоммуникационная технология подкастинга, сервис подкастов, подкаст, система упражнений.

Vashchylo O. National Technical University of Ukraine "Igor Sikorsky Kyiv Polytechnic Institute" Podcasting technology in the process of teaching ESP monologue speech to students majoring in mechanical engineering

Abstract. Introduction. The article outlines the issue of podcasting technology implementation in the process of teaching ESP monologue speech to the students majoring in mechanical engineering. The set of tasks, which envisages the use of podcasting technology both in-class and out-of-class, has been suggested. Purpose. To present the set of the tasks devised for the stated purpose and to confirm its efficiency. Methods. Thorough the analysis of the scientific studies concerning the issue of podcasting technology usage in the process of the second language acquisition has been conducted. Various approaches and suggestions on the problem have been considered. The aforementioned approaches serve a theoretical and methodological basis for the set of tasks development. Results. In the article the methodological characteristics of a podcasting terminal are enumerated with a view to justifying benefits of its application in the teaching process. The notion "set of tasks" is defined, the underlying didactic and methodological principles of its development are mentioned. The monologue speech skills are 
specified and systematized. The stages of the ESP monologue speech teaching process to prospective mechanical engineers are suggested. The purpose of each stage is highlighted. The peculiarities of students' extracurricular activity organization mediated by podcasting technology are elucidated. The examples of the tasks to be performed by students in podosphere in the course of their extracurricular activity are given. Conclusion. Thus, the set of tasks with the use of podcasting technology for teaching ESP monologue speech to prospective mechanical engineers has been suggested and characterized, its effectiveness has been justified.

Key words: ESP monologue speech teaching, podcasting technology, podcasting terminal, podcast, set of tasks.

Постановка проблеми. Процес інтеграції України в Європейське суспільство надає низку можливостей вітчизняним фахівцям, зокрема в галузі знань "Механічна інженерія" (надалі інженери-механіки), отримати безцінний професійний досвід, підвищити кваліфікацію й продемонструвати власну компетентність, працюючи на іноземних підприємствах, беручи участь у міжнародних галузевих практичних конференціях, симпозіумах, програмах обміну кадрів, проходячи стажування за кордоном тощо. 3 огляду на це вагомого значення набуває питання підготовки нового покоління інженерів-механіків, які добре володіють англійською мовою, зокрема англійським професійно орієнтованим монологічним мовленням (АПОММ). Відповідно до Програми з англійської мови для професійного спілкування (Бакаєва, та ін., с. 2), випускник бакалаврату технічних спеціальностей має володіти іноземною мовою на рівні В2. Тобто, вже під час навчання у ЗВО студент повинен уміти виступити з повідомленням чи презентацією; висловити, аргументувати й довести свою думку з того чи іншого питання; прокоментувати отриману інформацію; описати науковий продукт, дати йому характеристику тощо. Водночас на опанування англійської мови студентами бакалаврату механікомашинобудівного інституту КПІ імені Ігоря Сікорського виділяється 216 год., 3 них лише 45 аудиторних год. (2 аудиторні год. на тиждень) на четвертому курсі, що, наше переконання, не $\epsilon$ достатнім. За таких умов постає необхідність розроблення ефективнішої системи вправ для навчання майбутніх інженерів-механіків АПОММ.

Наразі дедалі більше уваги в навчанні іноземної мови приділяється інформаційнокомунікаційним (інфокомунікаційним) технологіям (ІКТ). Тому, розробляючи систему вправ для навчання майбутніх фахівців у галузі механічної інженерії АПОММ, ми використовуємо один із видів ІКТ - інфокомунікаційну технологію подкастингу.

Питанню використання сервісу подкастів у навчальних цілях присвячено низку досліджень. Так, О.Ю. Малушко (Малушко, 2013) вважає перспективним формувати в магістрантів лінгвістики іншомовну аудитивну компетентність 3 допомогою подкастів, П.В. Сисоєв (Сысоев, 2014) на їхній основі розвиває вміння говоріння й аудіювання, І.О. Свстєгнєєва (Евстигнеева, 2013) акцентує на потенціалі подкастів розвивати у студентів дискурсивні вміння, Н.Г. Протазанова (2011) пропонує навчати студентів філологічних спеціальностей монологічного мовлення з використанням директорії подкастів. Однак питання розроблення системи вправ для навчання майбутніх фахівців у галузі механічної інженерії АПОММ, яка (система) передбачала б використання інфокомунікаційної технології подкастингу, наразі залишається невирішеним. Цим і зумовлюється актуальність досліджуваної проблеми.

Мета статті - запропонувати систему вправ для навчання майбутніх інженерів-механіків АПОММ 3 використанням інфокомунікаційної технології подкастингу та розглянути iii ефективність. Для цього ми передбачаємо вирішити такі завдання:

- проаналізувати методичні властивості сервісу подкастів задля обгрунтування доцільності його використання в навчанні АПОММ;

- виділити й систематизувати навички й уміння АПОММ, розвиток яких покликана забезпечити система вправ на відповідних етапах навчання;

- охарактеризувати розроблену систему вправ для навчання майбутніх інженерів-механіків АПОММ з використанням інфокомунікаційної технології подкастингу. 
Основні результати дослідження. Пропонована нами система вправ уміщує вправи, які передбачають використання інфокомунікаційної технології подкастингу та виконуються студентами як в аудиторії, так і під час позааудиторної роботи. Аудиторна робота передбачає виконання вправ на сприймання автентичного іншомовного подкасту, аналіз його структурних компонентів, засобів когезії, лексичних і граматичних особливостей, усне репродукування основних частин прослуханого подкасту, деталізоване відтворення змісту сприйнятого подкасту тощо. Слід зауважити, що автентичні іншомовні подкасти добираються викладачем 3 урахуванням попередньо визначених критеріїв добору й упорядковуються відповідно до тематичного мінімуму. Під подкастом розуміємо аудіо- чи відеозапис, розміщений будь-яким користувачем у мережі Інтернет на сервісі подкастів (Сысоев, 2014, с. 189).

Позааудиторне навчання студентів передбачає їхню роботу із сервісом подкастів, організованим викладачем у мережі Інтернет на навчальній платформі Canvas шляхом розміщення на ній іншомовних автентичних подкастів і розроблених до них вправ. Працюючи з сервісом подкастів, студенти слухають розміщені викладачем подкасти й виконують завдання до них; створюють, редагують і публікують на сервісі власні монологічні висловлювання.

До методичних можливостей сервісу належать:

- створення без спеціальних знань програмування на сервісі подкастів особистої зони користувача;

- неодноразового прослуховування та/чи перегляду студентами в зручний для них час розміщених на сервісі викладачем англомовних подкастів;

- публікації на сервісі власних подкастів користувачів;

- перегляду подкастів, створених й опублікованих на сервісі учасниками робочої групи / інших груп;

- коментування подкастів, розміщених учасниками робочої групи / інших груп.

Розглянемо й охарактеризуємо розроблену нами систему вправ для навчання майбутніх інженерів-механіків АПОММ. Розробляючи іiі, ми керувались загальнодидактичними й методичними принципами навчання: активності, інтеграції зі спеціальними дисциплінами, диференціації й інтеграції у навчанні видів мовленнєвої діяльності, проблемної подачі матеріалу, автономності й самостійності, новизни й мотивації, тематичної організації матеріалів, ситуативності навчання тощо. Систему вправ для навчання монологічного мовлення визначасмо як сукупність ефективних типів і видів вправ, яка забезпечує послідовний розвиток навичок і вмінь АПОММ (Шатилов, 1985, с. 37) і розробляється з урахуванням визначених дидактичних i методичних принципів навчання та реалізується на певних етапах із використанням інфокомунікаційної технології подкастингу. Внаслідок аналізу низки наукових робіт ми визначили навички й уміння, розвиток яких покликаний сприяти формуванню у майбутніх інженерівмеханіків іншомовної професійно орієнтованої комунікативної компетентності в монологічному мовленні, й організували їх у групи з урахуванням зростання рівня складності. (Нижче наведено стислий перелік мовленнєвих навичок і вмінь АПОММ).

Група 1. Навички

- аналізувати логіко-композиційну побудову зразка мовлення;

- орієнтуватись у мовному матеріалі, як підгрунтя вміння розпізнавати загальнонаукові й науково-технічні терміни, а також синтаксичні структури з їх подальшою семантизацією.

Група 2. Уміння

- свідомого аналізу тексту подкаста 3 метою: його осмислення, розуміння, членування на смислові значеннєві відрізки, виділення й фіксації основної інформації у вигляді ключових слів, денотатних словосполучень, тема-рематичних єдностей;

- висловлюватись щодо змістовного аспекту сприйнятого подкасту:

- стисло / достатньо повно передавати зміст почутого подкасту;

- репродукувати почутий текст з опорою на зафіксовану інформацію. 
Група 3. Уміння продукувати власне монологічне висловлювання на основі критичного аналізу одержаної з подкасту інформації (розвиваються під час позааудиторної роботи студентів з використанням сервісу подкастів):

- висловлювати ставлення до почутої інформації, перерахувати переваги й недоліки, аргументуючи свою позицію та пояснюючи хід мислення;

- оцінити актуальність теми, новизну, рівень пізнавальності, змістовність, цінність почутої інформації, глибину висвітлення наукової проблеми;

- формулювати висновки, які є логічним узагальненням усього сказаного;

- продукувати монологічне висловлювання, яке характеризується логічністю, зв'язністю, лексичною й граматичною правильністю, різноманітністю мовних засобів на основі сприйнятого подкасту й з урахуванням власного досвіду.

Група 4. Уміння вирішувати проблемне завдання в робочих групах і складати спільне монологічне висловлювання за результатами вирішення:

- знайти, проаналізувати й вилучити інформацію, необхідну для вирішення проблемного завдання із запропонованих викладачем джерел (подкасти, друковані тексти) чи мережі Інтернет з її письмовою фіксацією за необхідності;

- збирати, обробляти й синтезувати індивідуальні результати партнерів і створювати кінцевий сумісний продукт діяльності;

- відібравши найсуттєвіше, об’єднати й узагальнити у формі монологічного висловлювання, зважаючи на задану ситуацію професійної діяльності.

Уміння представляти спільно віднайдене вирішення проблемного завдання перед аудиторією в певній ситуації професійної діяльності з подальшим фронтальним обговоренням.

Група 5. Уміння знаходити вирішення проблемного завдання, розміщеного викладачем на сервісі подкастів, з подальшим його представленням у формі монологічного висловлювання й розміщенням на сервісі подкастів (удосконалюються під час позааудиторної роботи студентів з використанням сервісу подкастів):

- здійснювати самостійний пошук і відбір інформації, знаходити рішення проблеми;

- продукувати монологічне висловлювання, в якому представлено обгрунтоване, логічне, актуальне, 3 елементами новизни й можливістю прикладного застосування вирішення професійного завдання.

У сучасній методичній літературі зазначається, що розвиток умінь монологічного мовлення здійснюється поетапно. В межах нашого дослідження процес навчання усного монологічного мовлення пропонуємо реалізувати в три етапи: рецептивний, рецептивно-репродуктивний і продуктивний. Виконання вправ на кожному з виділених етапів покликане сприяти реалізації певного завдання. Завдання кожного з етапів представлено в табл. 1.

\section{Етапи навчання майбутніх інженерів-механіків АПОММ}

Таблиия 1

\begin{tabular}{|c|c|}
\hline Етап навчання & Завдання етапу \\
\hline Рецептивний & Вдосконалення навичок \\
Рецептивно-репродуктивний & Розвиток умінь АПОММ \\
Продуктивний & Вдосконалення вмінь АПОММ \\
\hline
\end{tabular}

Пропонована система вправ для навчання майбутніх інженерів-механіків АПОММ містить три групи вправ, кожна з яких складається із певних підгруп, і реалізується на певному етапі навчання. Група вправ 1 для вдосконалення мовленнєвих навичок реалізується на рецептивному етапі й складається з трьох підгруп вправ: для вдосконалення навичок коректної композиційної побудови висловлювання (підгрупа 1.1); для вдосконалення лексичних навичок (підгрупа 1.2); для вдосконалення граматичних навичок (підгрупа 1.3). Група вправ 2 для розвитку вмінь 
АПОММ реалізується на рецептивно-репродуктивному етапі й містить три підгрупи вправ: у смисловому аналізі сприйнятого подкасту (підгрупа 2.1); у частковому й детальному відтворенні змісту сприйнятого подкасту (підгрупа 2.2); у продукуванні власного монологічного висловлювання на основі критичного аналізу інформації з подкасту, розміщеного викладачем на сервісі подкастів, які виконуються студентами під час позааудиторної роботи (підгрупа 2.3). Група вправ 3 для вдосконалення вмінь продукувати монологічне висловлювання за результатами вирімення проблемного завдання реалізується на продуктивному етапі й охоплює: вправи на знаходження, аналіз, вилучення, узагальнення, письмову фіксацію інформації в процесі пошуку колективного вирішення наявної проблеми в робочих групах, вправи на публічне представлення монологічного висловлювання і ситуаціях професійної діяльності з подальшим фронтальним обговоренням (підгрупа 3.1); вправи в створенні монологічного висловлювання за результатами вирішення проблемного завдання, розміщеного викладачем на сервісі подкастів, які виконуються студентами під час позааудиторної роботи, 3 подальшим його розміщенням на сервісі подкастів (підгрупа 3.2).

У табл. 2 наведено особливості організації роботи студентів з сервісом подкастів під час позааудиторної роботи на рецептивно-репродуктивному й продуктивному етапах.

Особливості організації позааудиторної роботи студентів з використанням навчального сервісу подкастів

\begin{tabular}{|c|}
\hline Робота з сервісом подкастів на рецептивно-репродуктивному етапі \\
\hline Студент \\
\hline $\begin{array}{l}\text { Виконує завдання на осмислення, аналіз, оцінку, аргументацію власної точки зору } \\
\text { до англомовних подкастів, розміщених викладачем на сервісі. } \\
\text { У процесі виконання завдання: } \\
\text { - прослуховує, осмислює, розуміє англомовні подкасти; } \\
\text { - продукує власне монологічне висловлювання з елементами узагальнення, доповнення, } \\
\text { порівняння, висловлення власної позиції з її аргументацією, співвіднесення сприйнятої } \\
\text { інформації подкасту з фаховими знаннями. За необхідності здійснює пошук додаткової } \\
\text { інформації у мережі Інтернет. }\end{array}$ \\
\hline $\begin{array}{l}\text { Записує власне англійське монологічне висловлювання за допомогою програм аудіозапису, } \\
\text { прослуховує та редагує його. Завдяки багаторазовості здійснення низки аналогічних } \\
\text { операцій (запис, прослуховування, редагування) розвиваються й удосконалюються вміння } \\
\text { продукування монологічного висловлювання, зокрема вмінь будувати висловлювання } \\
3 \text { усіма притаманними йому характеристиками й умінь говорити виразно, емоційно, } \\
\text { в нормальному темпі, висловлюватися логічно, зв’язно. }\end{array}$ \\
\hline $\begin{array}{l}\text { Публікує на сервісі подкастів остаточний варіант англійського професійно орієнтованого } \\
\text { монологічного висловлювання. }\end{array}$ \\
\hline Викладач \\
\hline $\begin{array}{l}\text { Контролює наявність розміщеного студентом подкасту. Прослу } \\
\text { (за необхідності розміщує коментарі) й оцінює рівень вико } \\
\text { до встановлених критеріїв. }\end{array}$ \\
\hline Робота з сервісом подкастів на продуктивному етапі \\
\hline \\
\hline $\begin{array}{l}\text { Аналізує проблемне завдання, результат вирішення якого необхідно представити у вигляді } \\
\text { монологічного висловлювання. В процесі вирішення проблемного завдання: } \\
\text { - здійснює самостійний пошук інформації, в тому числі в мережі Інтернет (зокрема } \\
\text { на сайтах, рекомендованих викладачем); } \\
\text { - виділяє й письмово фіксує релевантну інформацію з проблеми; }\end{array}$ \\
\hline
\end{tabular}


Продовження табл. 2

\section{Студент}

- знаходить рішення проблеми, спираючись на зафіксовану інформацію й знання з фахових дисциплін;

- створює розгорнуту програму власного монологічного висловлювання у вигляді логікосинтаксичних, логіко-семантичних і структурних схем;

- 3 опорою на створену програму продукує монологічне висловлювання, в якому подає вичерпне, грунтовне, професійно зумовлене, логічне, актуальне, з елементами новизни й можливістю прикладного застосування, вирішення проблеми.

Записує власне англійське професійно орієнтоване монологічне висловлювання, прослуховує, редагує й публікує остаточний варіант на навчальному сервісі подкастів.

\section{Викладач}

Проводить моніторинг результатів самостійної роботи студентів.

Прослуховує опубліковані навчальні подкасти, за необхідності розміщує коментарі з приводу рівня виконання завдання.

Оцінює рівень виконання завдання відповідно до встановлених критеріїв.

Запропоновану систему вправ для навчання майбутніх інженерів-механіків АПОММ 3 використанням інфокомунікаційної технології подкастингу докладніше представлено в табл. 3 . Наведемо приклади вправ другої (2.2 і 2.3) і третьої групи (3.1 і 3.2).

Група 2 підгрупа 2.2. Вправа 1. Тип: рецептивно-продуктивна, комунікативна.

Мета: розвиток уміння висловлюватись щодо змістовного аспекту почутого тексту: вміння докладно переказувати почутий текст з опорою на зафіксовану інформацію у вигляді ключових слів, денотатних словосполучень, тема-рематичних єдностей.

Task: Divide into small groups, listen to the podcast on Advance Manufacturing Precision CNC Machining. Every member of the group has to note down information on the given topic using key words/phrases/sentences and, based on their notes, deliver an extended speech in front of the colleagues.

\begin{tabular}{|c|l|l|}
\hline \multicolumn{1}{|c|}{ Student } & \multicolumn{1}{|c|}{ Topic } & Key words/phrases/sentences \\
\hline Student 1 & Facility and equipment & \\
\hline Student 2 & Engineering department & \\
\hline Student 3 & Website and industries & \\
\hline Student 4 & Quality centre & \\
\hline
\end{tabular}

Опора: ключові слова, денотатні словосполучення, тема-рематичні єдності

Спосіб виконання: у міні-групах

Спосіб контролю: взаємоконтроль, контроль з боку викладача 


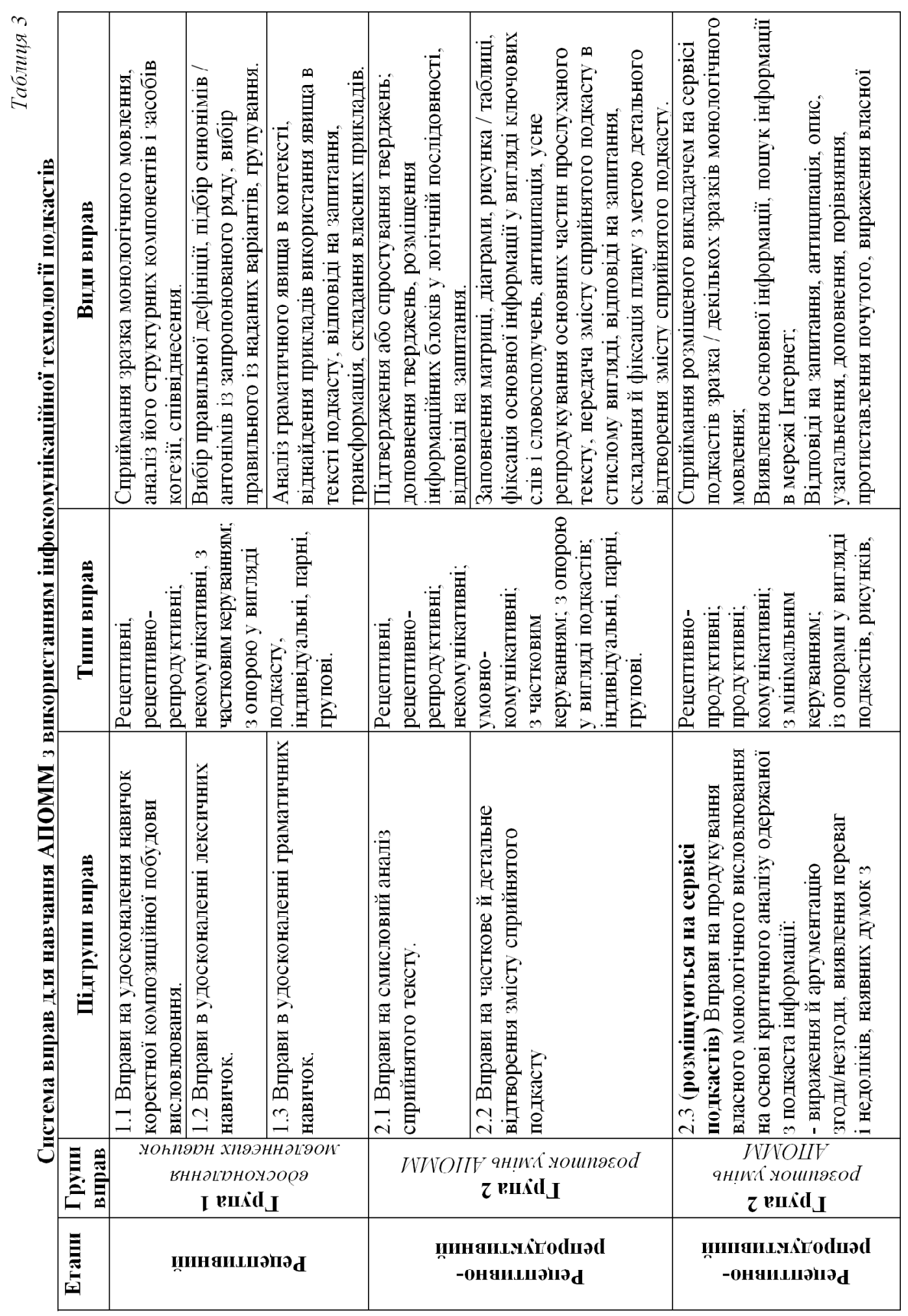




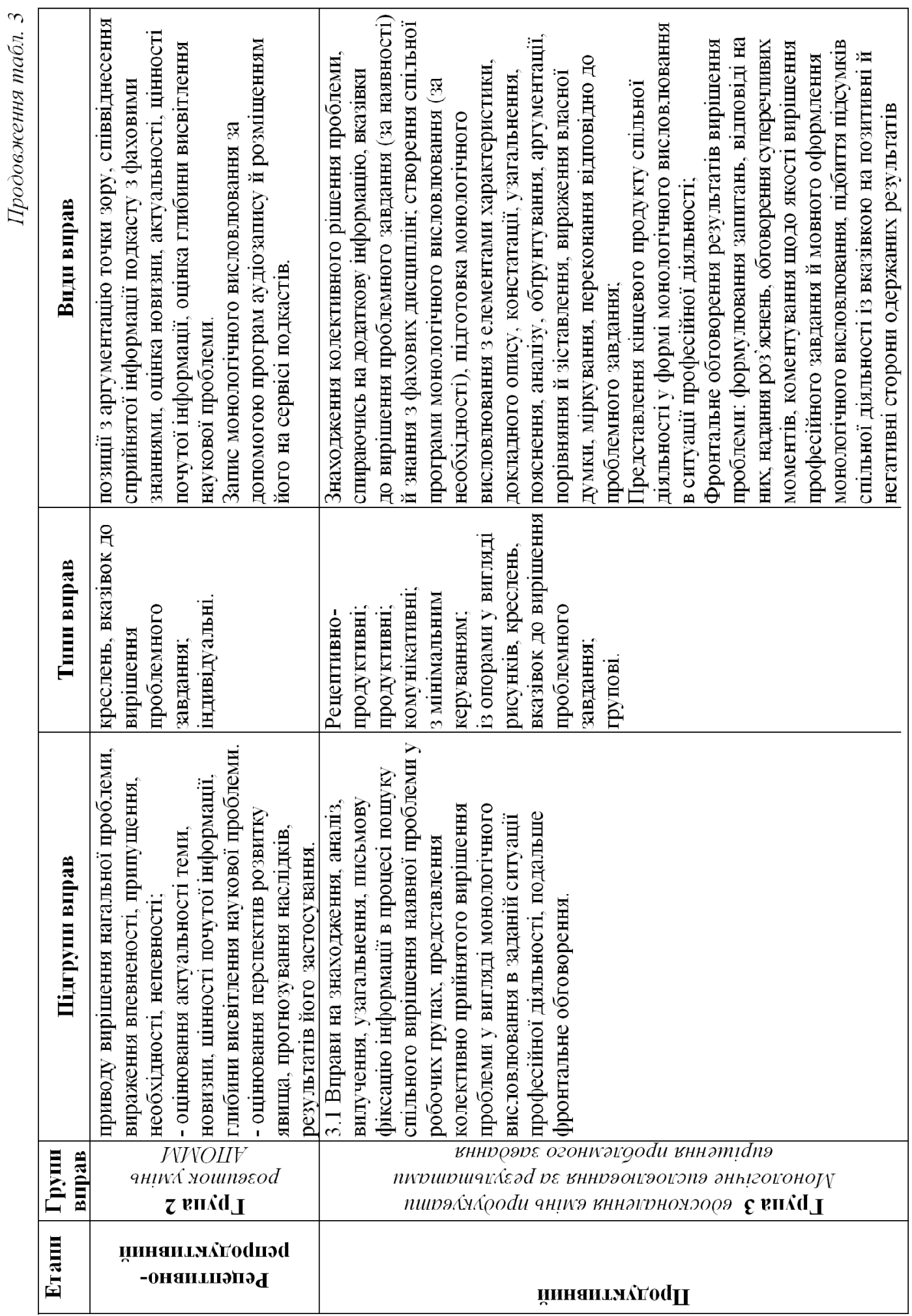




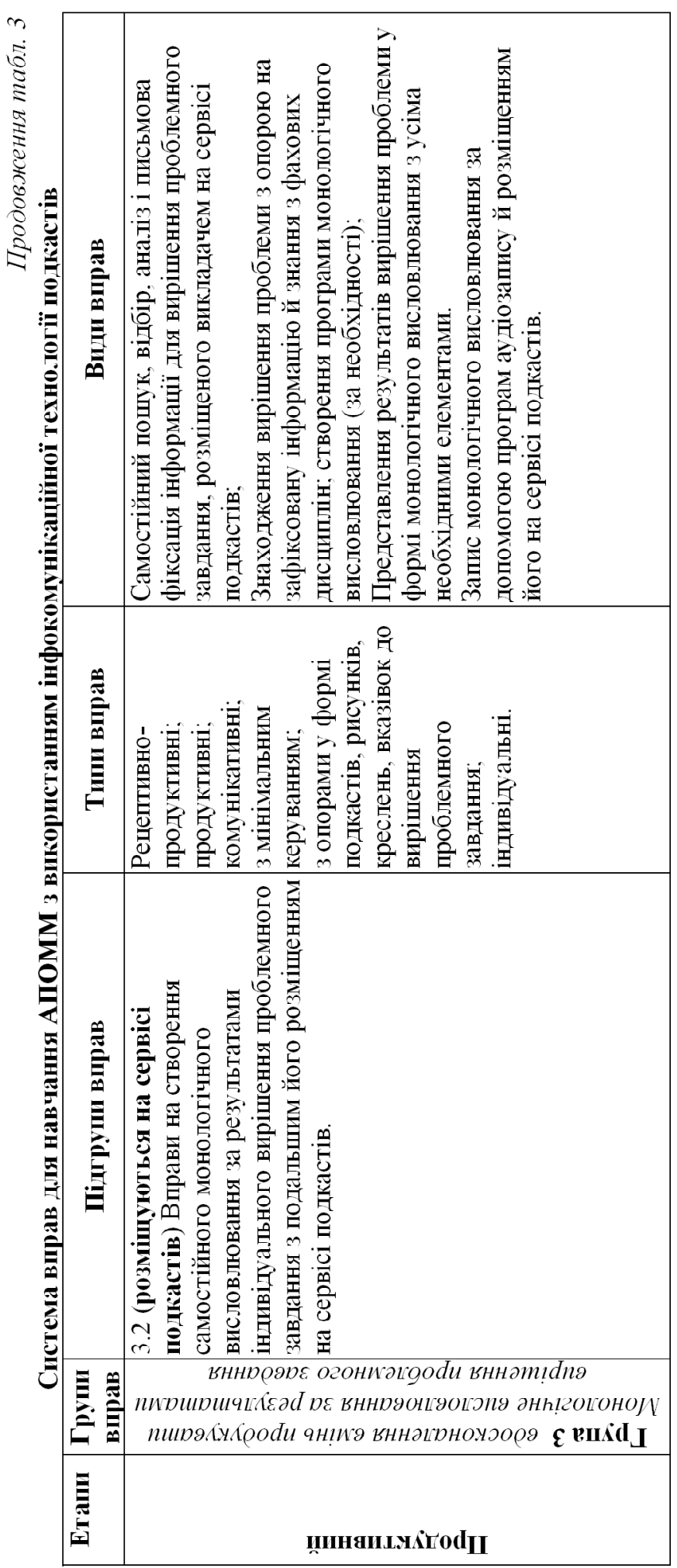


Група 2 підгрупа 2.3. Вправа 2. Тип: рецептивно-продуктивна, комунікативна.

Мета: розвиток уміння продукувати зв'язне монологічне висловлювання на основі логічних умовиводів, критичного аналізу одержаної з подкасту інформації.

Task: Listen to the podcast and answer the questions below justifying your opinion and explaining your reasoning. If necessary, use additional information from the World Wide Web.

$>$ Give detailed description of the information from the podcast;

$>$ Enumerate advantages and disadvantages of the gear manufacturing process;

D Evaluate the given information from professional point of view, give recommendations to your colleagues on its importance;

> Summarize, indicating well, poorly covered issues of the problem at hand, express personal attitude to the matter.

Спосіб виконання: індивідуально

Спосіб контролю: самоконтроль, контроль 3 боку викладача

Група вправ 3, підгрупа 3.1. Вправа 3. Тип: продуктивна, комунікативна

Мета: розвиток уміння усвідомити проблемне завдання; уміння представляти вирішення у формі монологічного висловлювання з елементами аналізу, синтезу, доказу.

Task: You were invited to deliver a speech at the International Scientific Conference, dedicated to the actual problems in Mechanical Engineering. Your speech elicits the problem of the most appropriate kind of casting selection with the view to carrying out the analysis of the casting block (see Fig. 1). To do this, describe and analyze the existing kinds of casting. Rationalize your choice and deliver the report at the conference.

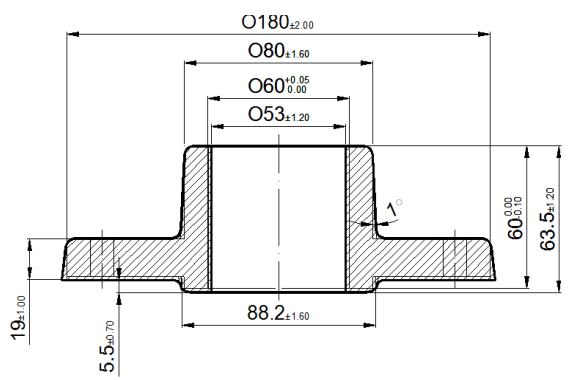

Рис. 1. Лита заготовка

Опора: рисунок

Спосіб виконання: групова

Спосіб контролю: взаємоконтроль, контроль 3 боку викладача

Група вправ 3, підгрупа 3.2. Вправа 4. Тип: продуктивна, комунікативна

Мета: розвиток уміння здійснювати самостійний пошук і відбір інформації; уміння продукувати монологічне висловлювання, в якому представлено обгрунтоване, логічне, актуальне, 3 елементами новизни й можливістю прикладного застосування вирішення професійного завдання; уміння запису, редагування й публікації на сервісі подкастів остаточного варіанту власного англійського професійно орієнтованого монологічного висловлювання.

Task: In the framework of the development of the manufacturing process of the arm support bracket (Fig. 2), describe the service purpose and operating conditions of the part at the site. With the view to fulfilling the task:

$>$ define the class to which the part belongs;

$>$ analyze the shape, precision and quality of surface parts manufacturing;

$>$ analyze the accuracy of their placement with regard to other surfaces; 
material;

pay attention to the name of the parts, technical specifications of its production and the

$>$ determine the possible method of manufacturing a workpiece.

Produce a speech based on the results of the task, record it using the audio recording program and upload it on the podcasting terminal.

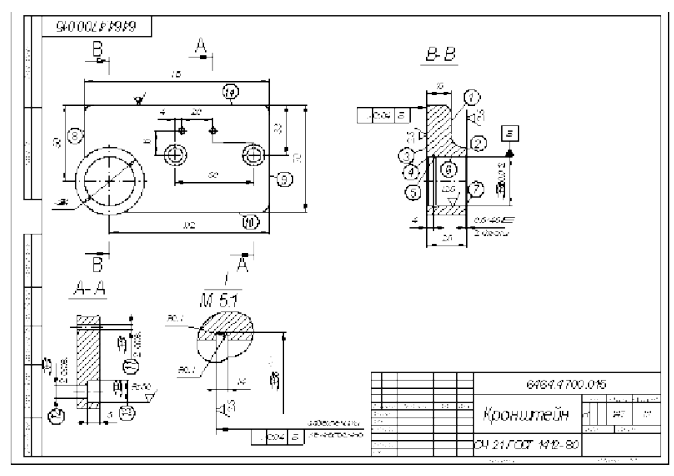

Рис. 2. Кронштейн

Опора: рисунок

Спосіб виконання: індивідуально

Спосіб контролю: самоконтроль, контроль з боку викладача

Таким чином, ми представили й охарактеризували систему вправ для навчання майбутніх інженерів-механіків АПОММ з використанням інфокомунікаційної технології подкастингу, які (вправи) проілюстрували прикладами. Перспективним для подальшого дослідження $є$ розроблення моделі процесу навчання майбутніх інженерів-механіків АПОММ із використанням сервісу подкастів.

\section{ЛIТЕРАТУРА}

Бакаєва, Г.С., Борисенко, О.А., Зуєнок, І.І., Іваніщева, В.О., Клименко, Л.Й., Козимирська, Т.І. ... Ходцева А.О. (2005). Програма з англійської мови для професійного спілкування. Київ: Ленвіт.

Евстигнеева, И.А. (2013). Методика развития дискурсивных умений студентов на основе современных информачионных и коммуникационных технологий (английский язык, языковый вуз) (Кандидатская диссертация). Москва, Московский государственный гуманитарный университет им. М.А. Шолохова, Москва, Российская Федерация.

Малушко, Е. Ю. (2013). Методика формирования иноязычной профильной аудитивной компетенции магистрантов лингвистики (на основе инфокоммуникационной технологии подкастов, английский язык) (Кандидатская диссертация). Пятигорск, ФГБОУ ВПО "Пятигорский государственный лингвистический университет", Российская Федерация.

Протазанова, Н.Г. (2011). Использование сочиального сервиса подкастов в обучении иностраннымм языкам. Ярославский педагогический вестник, 3 (II), 95-97.

Сысоев, П.В. (2014). Подкасты в обучении иностранному язику. Язык и культура, 2 (26), 189-201. Шатилов, С.Ф. (1985). Актуальные проблемы методики обучения русскому языку иностранных учашихся. Ленинград: ЛГУ.

\section{REFERENCES}

Baka€va, G.C., Borisenko, O.A., Zuєnok, I.I., Ivanishheva, V.O., Klimenko, L.J., Kozimirs'ka, T.I. ... Hodceva A.O. (2005). Programa z anglijs'koï movi dlja profesijnogo spilkuvannja. Kiïv: Lenvit. 
Evstigneeva, I.A. (2013). Metodika razvitija diskursivnyh umenij studentov na osnove sovremennyh informacionnyh i kommunikacionnyh tehnologij (anglijskij jazyk, jazykovyj vuz) (Kandidatskaja dissertacija). Moskva, Moskovskij gosudarstvennyj gumanitarnyj universitet im. M.A. Sholohova, Moskva, Rossijskaja Federacija.

Malushko, E. Ju. (2013). Metodika formirovanija inojazychnoj profil'noj auditivnoj kompetencii magistrantov lingvistiki (na osnove infokommunikacionnoj tehnologii podkastov, anglijskij jazyk) (Kandidatskaja dissertacija). Pjatigorsk, FGBOU VPO "Pjatigorskij gosudarstvennyj lingvisticheskij universitet", Rossijskaja Federacija.

Protazanova, N.G. (2011). Ispol'zovanie social'nogo servisa podkastov v obuchenii inostrannym jazykam. Jaroslavskij pedagogicheskij vestnik, 3 (II), 95-97.

Sysoev, P.V. (2014). Podkasty v obuchenii inostrannomu jaziku. Jazyk i kul'tura, 2 (26), 189-201.

Shatilov, S.F. (1985). Aktual'nye problemy metodiki obuchenija russkomu jazyku inostrannyh uchashhihsja. Leningrad: LGU. 